\title{
The effect of strain amount on corrosion behavior of EDDQ steel sheet
}

\section{Vplyv stupňa deformácie na korózne vlastnosti hlbokot’ažného ocel'ového plechu}

\author{
Brezinová J., Slota J., Tomáš M., Koncz J. \\ TU Košice \\ E-mail: janette.brezinova@tuke.sk
}

This paper presents the results of research aimed to measuring the corrosion properties of EDDQ steel sheet. The strain amount influence to the corrosion properties of the steel sheet for drawn parts has been proven by the modern methods of corrosion monitoring such as Electrochemical Impedance Spectroscopy. Corrosion rate was assessed using electrochemical methods in $0.1 \mathrm{M}$ solution of $\mathrm{NaCl}$. Experimental studies have pointed out if strain amount increases the corrosion rate of the steel sheet increases too.

\section{INTRODUCTION}

Recent trends in the manufacture of car bodies are aimed at using advanced high strength and ultrahigh strength steels. These steels reach to high level of mechanical properties. Elimination of steel body weight using advanced materials is one of the major trends in the design of cars. In the manufacture of cars are used coated body sheets which are subjected to acid rain, temperature differences, sunlight, oxygen, road salt etc. throughout their lifetime. Therefore, corrosion protection is a very important part of the car production process. Body sheet metal used for making car body are normally zinc galvanized or modified in other ways (e.g. by cataphoresis). The zinc is non-noble metal with tendency to passivation. When it is contacted with the steel, it behaves as anode and suppresses activity of the steel, which is base for the corrosion protection of metallic materials [1-4]. Protective zinc coating has to provide higher resistance of the whole protective system against perforation corrosion of body sheets. Another function of $\mathrm{Zn}$ coating is the longest corrosion protection in cavities and crevices where the coating system is poor or incomplete. Automobile steel sheets are hot dip galvanized or electrogalvanized. $\mathrm{Zn}$ coating may be single or double sided. Zinc-coated car body sheets show high corrosion resistance. During deformation seizing of zinc coating, failure of cohesion between $\mathrm{Zn}$ coatings and the substrate or exposures of the base material surface often occur. In car body sheets it is necessary to monitor the deformation process itself and the effect of deformation on the zinc coat $[5,6]$. The important
Príspevok prezentuje výsledky výskumu ziskané meraním koróznych vlastnosti hlbokotažnej ocele. Vplyv stupňa deformácie na korózne vlastnosti ocel'ového plechu pre hlboké t'ahanie bol identifikovaný modernými metódami monitoringu korózie, ako je elektrochemická impedančná spektroskopia. Korózna rýchlost' bola hodnotená pomocou elektrochemickej metódy v $0.1 \mathrm{M}$ roztoku $\mathrm{NaCl}$. Výsledky experimentov ukázali, že zvyšovaním stupňa deformácie sa korózna rýchlost'ocel'ového hlbokot'ažného plechu tiež zvyšuje.

thing is to find out how the degree of deformation affects the corrosion characteristics of $\mathrm{Zn}$ coating (the current density, corrosion potential, corrosion rate and polarization resistance). The presented contribution aims at determination the effect of car body steel sheet deformation on change the corrosive properties of the applied coating using an Electrochemical Impedance Spectroscopy $[7,8]$.

\section{EXPERIMENTAL PROCEDURE}

Test samples for experimental research have been supplied in a state after deformation of the cold rolled steel sheet DC 06 (EN 10130). Chemical composition of the base material is shown in Table 1 and mechanical properties are in Table 2.

Tab. 1. Chemical composition of base material DC06 in \% by weight / Chemické zloženie základného materiálu DC06 $v h m . \%$

\begin{tabular}{|c|c|c|c|c|}
\hline $\mathbf{C}$ & $\mathbf{M n}$ & $\mathbf{P}$ & $\mathbf{S}$ & $\mathbf{T i}$ \\
\hline 0.020 & 0.250 & 0.020 & 0.020 & 0.300 \\
\hline
\end{tabular}

Tab. 2. Mechanical properties of base material DC06 / Mechanické vlastnosti základného materiálu DCO6

\begin{tabular}{|c|c|c|c|c|}
\hline $\mathbf{R}_{\mathbf{p} 0,2}(\mathbf{M P a})$ & $\mathbf{R}_{\mathbf{m}} \mathbf{( M P a )}$ & $\mathbf{A}_{\mathbf{8 0}}(\mathbf{\%})$ & $\mathbf{r}_{\mathbf{m}}(-)$ & $\mathbf{n}_{\mathbf{m}}(\mathbf{-})$ \\
\hline 148 & 293 & 48.9 & 1.753 & 0.258 \\
\hline
\end{tabular}


The base material was coated by double-side zinc ZE $75 / 75$, coating weight of $54 \mathrm{~g} / \mathrm{m}^{2}$. Before biaxial deep drawing, the deformation grid of points $0.5 \mathrm{~mm}$ in diameter and $1 \mathrm{~mm}$ in horizontal and vertical distance was electrolytically etched on the surface for 3D optical photogrammetric measurement of drawn part's deformation. Subsequently, the deep drawing test with biaxial stress state was carried out on the test device Erichsen 145-60 using Nakajima tool. Test samples for measurement of corrosion properties have been taken from the four areas of drawn part: sample No. 1 - undeformed material, sample No. 2 - material with localised deformation, sample No. 3 - material above the fracture AND sample No. 4 - material from the highest point of the drawn part.

Thinning of the steel sheet was measured by 3D optical photogrammetric system ARGUS. Corrosion resistance of samples was determined by Electrochemical Impedance Spectroscopy using measurement device SP 150 Bio-Logic and software EC-Lab V10. The device can measure electrochemical parameters in different extent. Tafel analysis allows to determine corrosion current $i_{\text {corr }}$ (and also corrosion current density $\mathrm{I}_{\text {corr }}$ ) and corrosion potential $\mathrm{E}_{\text {corr }}$. The polarization resistance $\mathrm{R}_{\mathrm{p}}$ was determined by EIS as well. Measurement of electrochemical parameters was performed in $0.1 \mathrm{M}$ solution of $\mathrm{NaCl}$. Reference electrode was saturated calomel electrode, working electrode was test sample and auxiliary electrode was platinum electrode. Parameters used for the potentiodynamic tests were as follows: stabilization time was $600 \mathrm{~s}$; the polarization of the sample was performed in the range from $-150 \mathrm{mV}$ from the free corrosion potential to $+1000 \mathrm{mV}$ against the reference electrode; the rate of corrosion potential was

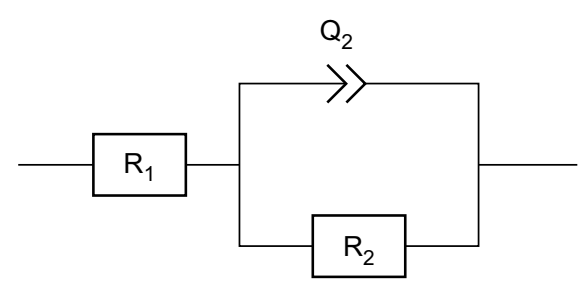

Fig. 1. Equivalent circuit for intact coating Obr. 1. Ekvivalentný obvod pre neporušený povlak

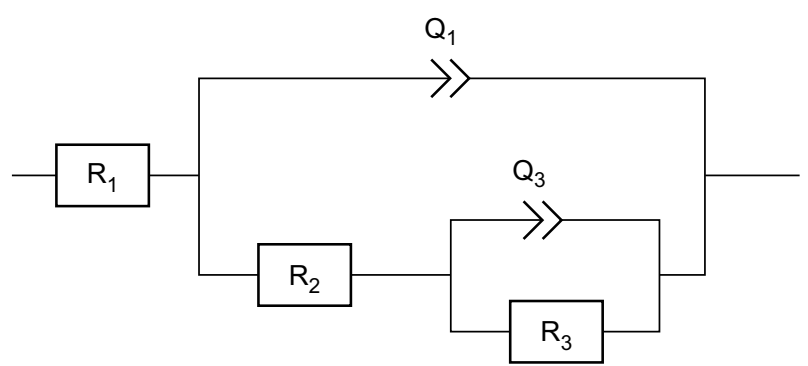

Fig. 2. Equivalent circuit for damaged coating Obr. 2. Ekvivalentný obvod pre porušený povlak
$1 \mathrm{mV} / \mathrm{s}$; the surface area was $0,636 \mathrm{~cm}^{2}$. The frequency change for the EIS varied from $100 \mathrm{kHz}$ to $1 \mathrm{mHz}$ with 10 points per decade, and the width of the sinusoidal voltage signal applied to the system was $5 \mathrm{mV}$.

For test samples No. 1, 3 and 4 an equivalent measuring circuit for the intact coating surface with a constant phase shift has been used as it is shown in Fig. 1, where R1 is the resistance of the electrolyte, R2 = Rp is the polarization resistance and Q2 is a constant phase element. For the sample No. 2 from the material with localised deformation an equivalent measuring circuit for the damaged coating surface with a constant phase shift has been used. The measuring circuit has been extended by R3 parameter representing the polarization resistance $(\mathrm{R} 3=\mathrm{Rp})$ near the failure, constant phase elements Q1representing the capacity of corrosion products, double layer Q3 and the resistance of electrolyte in the pores R2, Fig. 2.

\section{RESULTS}

Thickness of the steel sheet after deformation by biaxial stretching has been measured by photogrammetric system ARGUS. From the major strain (Fig. 3) and minor strain (Fig. 4) were calculated changes of thickness on the bulged sample. The thinning of steel sheet is shown in Fig. 5 in color scale. The thickness change distribution on bulged hemisphere depending on the developed length of the drawn part is shown in Fig. 6.

Thinning of the steel sheet after biaxial stretching shown in Fig. 5 is expressed as a percentage of initial steel sheet thickness $0.87 \mathrm{~mm}$. For sample No. 1 taken from the hemisphere bottom thickness of the material hasn't changed. The maximum thinning of $40 \%$ has been measured on the perimeter of crack where sample No. 2 has been taken. The sample No. 3 has been taken approx. $7 \mathrm{~mm}$ from the sample No. 2 and the thinning of $34 \pm 2 \%$ has been measured. The sample No. 4 has been taken at the top of the hemisphere where thinning of 17 $\pm 2 \%$ has been measured.

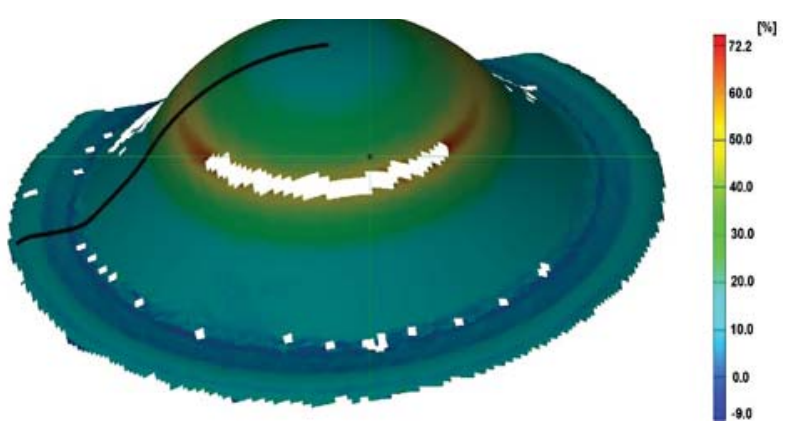

Fig. 3. Distribution of major strain on bulged sample of EDDQ steel sheet

Obr. 3. Rozloženie hlavnej deformácie na vzorke z hlbokotažnej ocele (EDDQ) po dvojosovom vypínaní 
Fig. 7 and Fig. 8 show corrosion potential $\mathrm{E}_{\text {corr }}$ and corrosion current density $\mathrm{I}_{\text {corr }}$ of samples measured by Tafel analysis. The lowest value $\mathrm{I}_{\text {corr }}$ was found in undeformed material - sample No. 1, the highest value has been found in area of material fracture - sample No. 2, where the highest thinning of $40 \%$ was achieved.

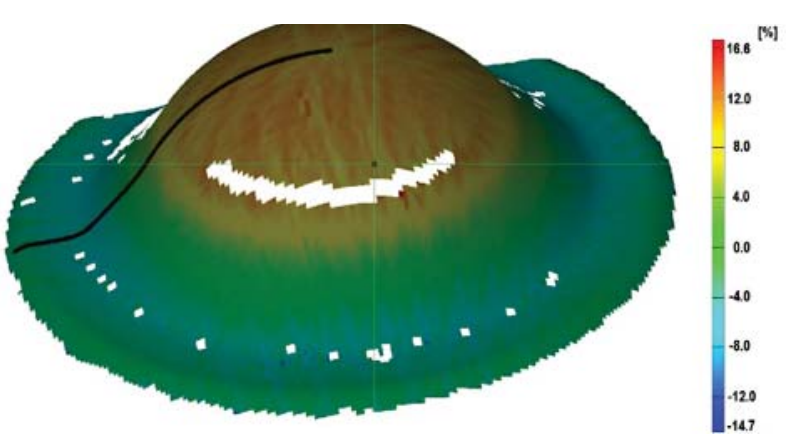

Fig. 4. Distribution of minor strain on bulged sample of EDDQ steel sheet

Obr. 4. Rozloženie vedl'ajšej deformácie na vzorke z hlbokotažnej ocele (EDDQ) po dvojosovom vypínaní

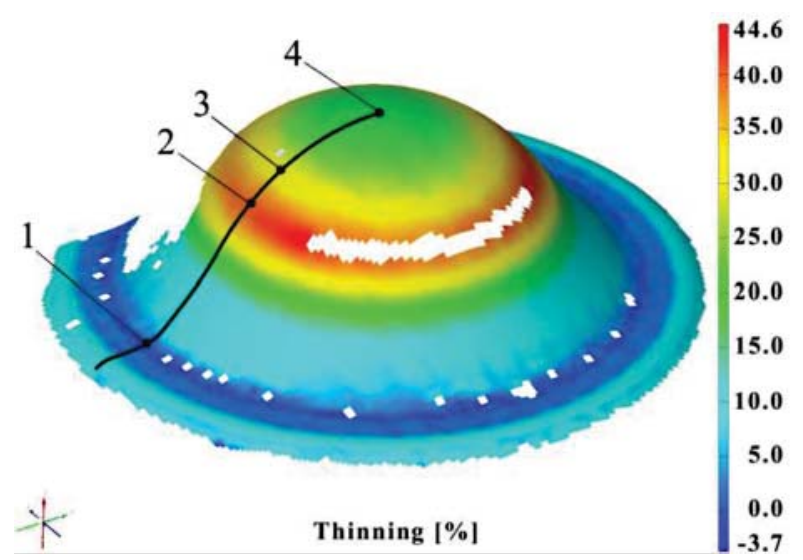

Fig. 5. Thinning of EDDQ sheet after biaxialstretching Obr. 5. Stenčenie EDDQ ocele po dvojosovom vypínaní

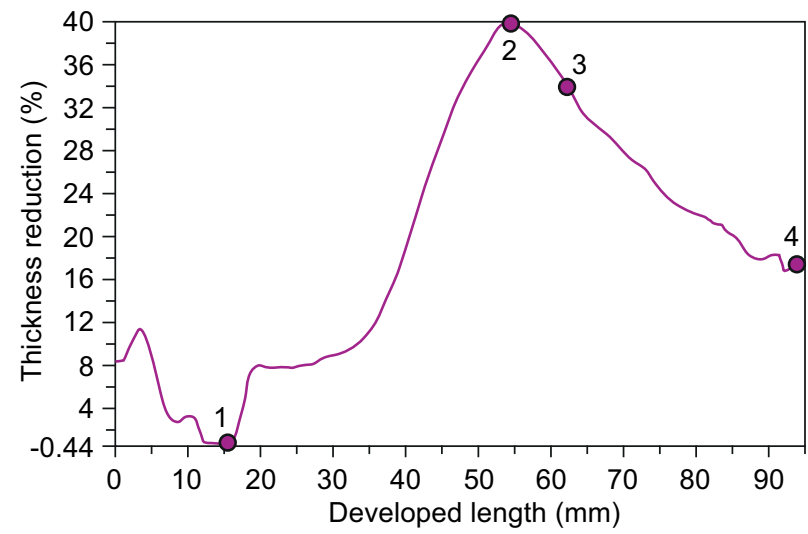

Fig. 6. Change of the material thickness after biaxial stretching

Obr. 6. Zmena hrúbky materiálu po dvojosovom vypínaní
Polarization resistance $R_{p}$ has been measured by EIS with values: $25 \mathrm{k} \Omega$ for sample No. 1 - undeformed base material; $1.25 \mathrm{k} \Omega$ for sample No. 2 - maximum deformation; $2.94 \mathrm{k} \Omega$ for sample No. 3 - above the fracture; $5.66 \mathrm{k} \Omega$ sample No. 4 - top of the dome. The lowest polarization resistance of $1.25 \mathrm{k} \Omega$ as well as the highest current density $i_{\text {corr }}$ of $16 \mu \mathrm{A}$ were found for sample No. 2 in the area of maximum deformation of the material. Thus, the higher probability of corrosion processes initiation is supposed. Experimentally measured results showed that the deformation of the material has a significant influence on the corrosion resistance of coatings applied.

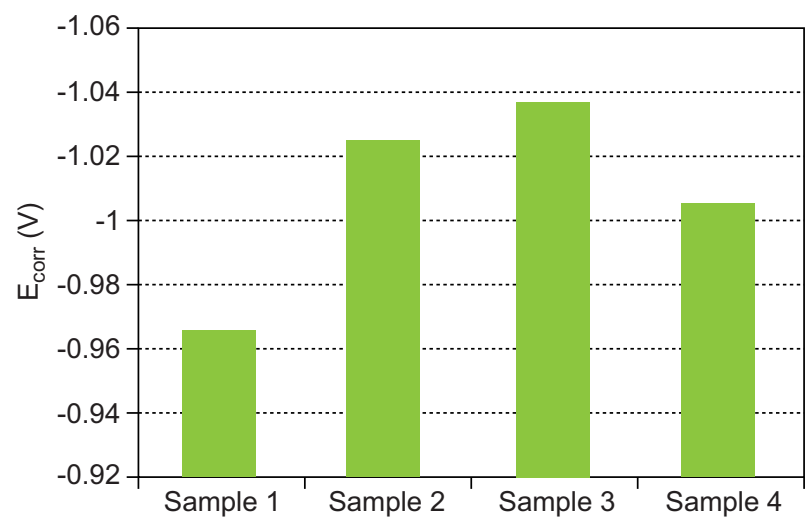

Fig. 7. Corrosion potential of $\mathrm{Zn}$ coating in measured areas Obr. 7. Korózny potenciál Zn povlaku v meraných oblastiach

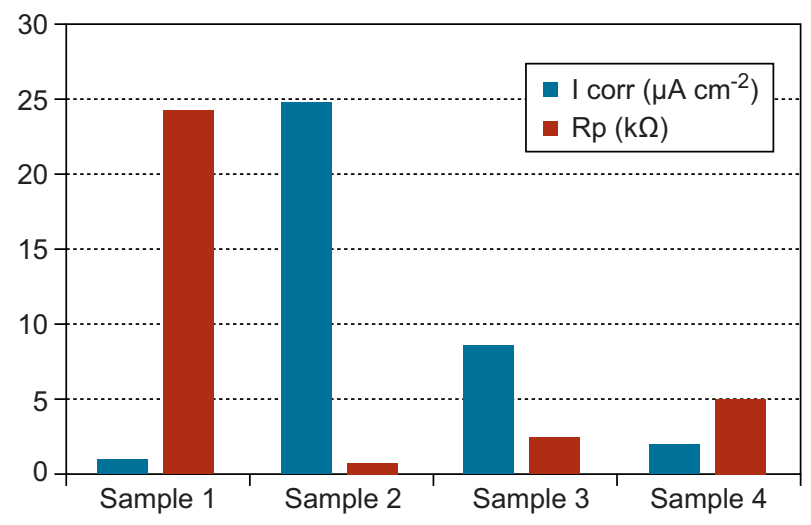

Fig. 8. Corrosion current density of $\mathrm{Zn}$ coating in measured areas

Obr. 8. Korózna prúdová hustota Zn povlaku v meraných oblastiach

The results of electrochemical impedance spectroscopy (Nyquist plots) are in Fig. 9. Figure 10 shows the potentiodynamic curves of the four exposed samples. The measurement locations (sample 1-4) are identical to those of Fig. 5. The fastest dissolution of the coating took place on the undamaged sample (sample 1) up to potential $-0.9 \mathrm{~V}$. After this value a very compact zinc oxide layer was created on the surface and the corrosion current 
growth was slowed down. Despite rapid corrosion the current of sample 1 was the lowest. Anodic part of the potentiodynamic curve (sample 4) can be divided into three areas. The first between $\mathrm{E}_{\text {corr }}$ and potential -0.93 with slow increase of $i_{\text {corr }}$ due to formation a thin film of corrosion products. The second area between $-0.93 \mathrm{~V}$ and $-0.89 \mathrm{~V}$ with a sharp increase of $\mathrm{i}_{\text {corr }}$ due to localized corrosion (damaged layer of corrosion products). Anodic part of the curve is very similar to the curve of the sample 3 .

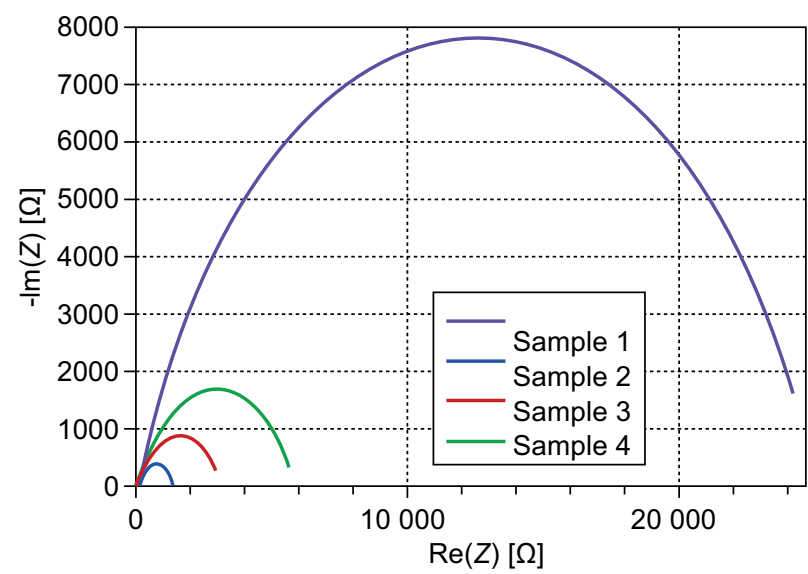

Fig. 9. Electrochemical impedance spectroscopy of EDDQ steel sheet

Obr. 9. Elektrochemická impedančná spektroskopia ocelového hlbokotažného plechu

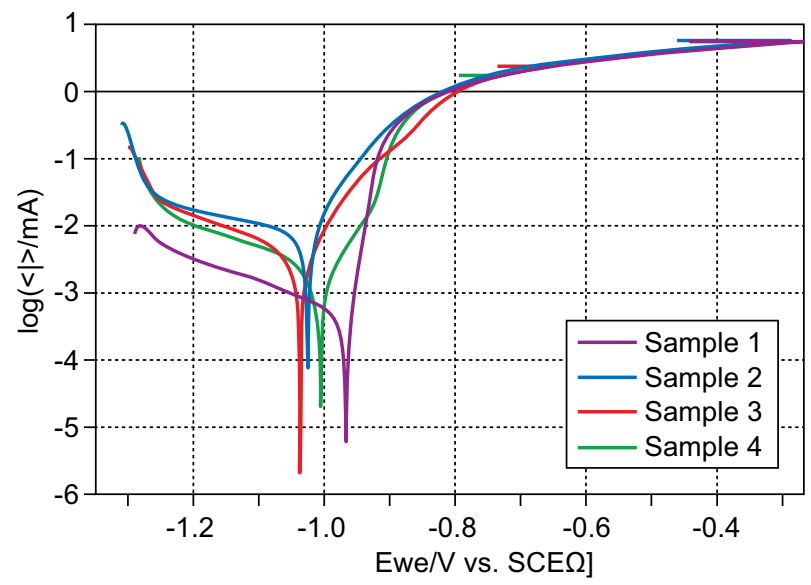

Fig. 10. Potentiodynamic curves of the four exposed samples

Obr. 10. Potenciodynamické krivky štyroch skúšaných vzoriek

\section{CONCLUSIONS}

Based on Tafel analysis of samples with different deformation degree, specified by the thinning of steel sheet, the corrosion potential value $\mathrm{E}_{\text {corr }}$ and the corrosion current density value $\mathrm{I}_{\text {corr }}$ have been determined. The results have pointed out the corrosion rate is affected mainly by the degree of deformation. Increasing the deformation degree has led to increasing the corrosion rate of zinc coating as well. Electrochemical impedance spectroscopy allowed finding out polarization resistance $\mathrm{R}_{\mathrm{p}}$. The highest polarization resistance was found in undeformed material, the lowest in the region of material fracture. The knowledge is consistent with the measured values of the corrosion current density. Experimental results point to the fact that the corrosion resistance of zinc coating is significantly affected by the degree of deformation.

\section{Acknowledgements}

The authors gratefully acknowledge the financial support of the project VEGA No. 1/0600/13 and KEGA 059TUKE-4/2016.

\section{REFERENCES}

1. Vratna, J., et al., Room temperature corrosion properties of AZ31 magnesium alloy processed by extrusion and equal channel angular pressing. J. Mater. Sci. 2013, 48, 45104516.

2. Bukovinova, L., Hadzima, B., Electrochemical characteristics of magnesium alloy AZ31 in Hank's solution. Corros. Eng. Sci. Technol. 2012, 47, 352-357.

3. Jafari, H., et al., EIS study of corrosion behavior of metallic materials in ethanol blended gasoline containing water as a contaminant, Fuel 2011, 90, 1181-1187.

4. Mouanga, M., Puiggali, M., Devos, O., EIS and LEIS investigation of aging low carbon steel with $\mathrm{Zn}-\mathrm{Ni}$ coating, Electrochim. Acta 2013, 106, 82-90.

5. Frącz, W., Stachowicz, F., Pieja, T., Aspects of verification and optimization of sheet metal numerical simulations process using the photogrammetric system, Acta Metall. Slovaca 2013, 19, 51-59.

6. Slota, J, et al., The sensitivity of a photogram. method in formability analysis, Acta Mechanica et Automatica 2013, 7, 117-123.

7. Barranco, V., Feliu Jr. S., Feliu, S., EIS study of the corrosion behaviour of zinc-based coatings on steel in quiescent $3 \%$ $\mathrm{NaCl}$ solution. Part 1: directly exposed coatings, Corros. Sci. 2004, 46, 2203-2220.

8. Walkner, S., Hassel, A.W., Combined chemical and EIS study of the reaction of zinc coatings under alkaline conditions, Electrochim. Acta 2014, 131, 130-136. 